\title{
Relationships between cell-specific growth rate and uptake rate of cadmium and zinc by a coastal diatom
}

\author{
Ai-Jun Miao, Wen-Xiong Wang* \\ Department of Biology, The Hong Kong University of Science and Technology, Clear Water Bay, Kowloon, Hong Kong, SAR
}

\begin{abstract}
Despite the fact that the influence of metal chemistry on metal uptake in marine phytoplankton has been well studied, the effects of physiological processes such as cellular growth remain less well known. In this study, the cell-specific growth rate of the coastal diatom Thalassiosira pseudonana (Clone-3H) was modified by 3 environmental factors: temperature, irradiance, and the light-dark (LD) cycle. Uptake of Cd and Zn was subsequently quantified using short-term exposure. These environmental factors significantly affected metal uptake. Cd and Zn uptake rates increased with increasing irradiance, temperature, and illumination period. We demonstrate that the metal uptake rate initially increased in proportion with an increase in cell-specific growth rate, and then remained constant. Uptake of $\mathrm{Cd}$ and $\mathrm{Zn}$ by the diatoms was not affected by 2 photosynthetic inhibitors, suggesting that their uptake was not affected by the photosynthetic activity. There was no obvious diel trend for metal uptake. Thus in this study, cell size, photosynthetic activity, and cell cycle were unlikely to have accounted for the variations in metal uptake at different temperatures, irradiances, and LD cycles. The dependence of metal uptake on cell-specific growth rate may have important implications for the prediction of metal accumulation by marine phytoplankton in different ecosystems or during phytoplankton blooms. Further studies are needed to examine the underlying mechanisms for such relationships at cellular and subcellular levels.
\end{abstract}

KEY WORDS: Diel variation $\cdot$ Growth rate $\cdot$ Inhibitor $\cdot$ Irradiance $\cdot$ Light-dark cycle $\cdot$ Temperature $\cdot$ Uptake rate

Resale or republication not permitted without written consent of the publisher

\section{INTRODUCTION}

There has been long-standing interest in trace-metal uptake by marine phytoplankton (Sunda \& Huntsman 1998a, 2000, Whitfield 2001). Many aspects of tracemetal uptake have been considered, including transport mechanisms, physiological and biochemical functions, and interactions of the metals (Sunda 1989, Hudson \& Morel 1990, Price \& Morel 1990, Bruland et al. 1991, Campbell 1995, Cullen et al. 1999). There have also been many studies on the effects of metal speciation and concentration on metal uptake by marine phytoplankton. The relationship between metal concentrations and uptake rates has been well established using trace-metal buffer solutions (Sunda \& Huntsman 1998a,b). Recent studies have also considered metal uptake by phytoplankton under different nutrient regimes (Wang \& Dei 2001, Wang et al. 2001), or metal and phosphate uptake under different iron concentrations (Cullen et al. 2003). However, very little work has been conducted on the effects of temperature, irradiance and the light-dark (LD) cycle (which are all important environmental variables in the ocean), on metal uptake by phytoplankton. Most metal-uptake experiments by marine phytoplankton have been conducted at the optimal temperature and light conditions for cell growth. Conversely, many studies have shown that biochemical composition, protein activity, and biovolume of the phytoplankton cells are greatly dependent on temperature and light (Harrison et al. 1990, Berges \& 
Harrison 1993, Lin \& Carpenter 1997, Berges et al. 2002, Hammer et al. 2002, Staehr et al. 2002). Whether or not these biological changes can affect metal uptake by the phytoplankton remains mostly unknown.

According to a simple kinetic equation, the tracemetal content in phytoplankton under steady-state conditions can be predicted by the metal uptake rate divided by the cell-specific growth rate of the cells (assuming that the metal efflux is negligible compared to the cell growth) (Sunda \& Huntsman 1998a). However, the interrelationship between cellular uptake rate and specific growth rate remains to be determined for further refinement of the kinetic equation (Wang \& Dei 2001). The previous few studies testing the interrelationship between specific growth rate and uptake rate were all performed by varying 1 environmental parameter (e.g. metal speciation, metal concentration, nutrient condition). Whether these factors can affect both metal uptake and cell growth simultaneously, or if there is an interaction between specific growth rate and uptake rate, is rather speculative. Understanding such an interaction has great implications on the prediction of metal dynamics in marine phytoplankton in response to a change in cell growth rate (e.g. bloom conditions) and thus their potential transfer to higher trophic levels. Nevertheless, this relationship has been seldom considered in previous studies.

In this study, 3 environmental factors (temperature, irradiance and the LD cycle) were used to modify the cell-specific growth rate of the coastal diatom Thalassiosira pseudonana. The $\mathrm{Cd}$ and $\mathrm{Zn}$ uptake rate was subsequently quantified and the interrelationship between metal uptake rate and specific growth rate of the diatom cells was tested. $\mathrm{Zn}$ is an important micronutrient to the phytoplankton, involved in the hydrolysis of phosphate esters, the replication and transcription of nucleic acids, and the hydration and dehydration of $\mathrm{CO}_{2}$ (e.g. carbonic anhydrase) (Sunda 1989). Cd can substitute for $\mathrm{Zn}$ when $\mathrm{Zn}$ is depleted, and has similar physiological functions in diatoms (Price \& Morel 1990, Lee et al. 1995, Cullen et al. 1999). To examine further whether the uptake of $\mathrm{Cd}$ and $\mathrm{Zn}$ is dependent on the photosynthetic system, we employed 2 photosynthetic inhibitors to suppress the photosynthetic activity of the cells. Recent studies have used these inhibitors to diagnose uptake mechanisms (Moye et al. 2002, Hassler \& Wilkinson 2003). Carbonyl cyanide m-chlorophenylhydrazone (CCCP) can disconnect electron transport from ATP synthesis, thereby inhibiting photophosphorylation and partly disrupting the energy production of the cells. The other inhibitor, the herbicide paraquat $\left(1,1^{\prime}-\right.$ dimethyl-4, 4'-bipyridinium) used in this study can accept electrons from Photosynthetic System I and inhibit the reduction of ferredoxin. We also tested metal uptake as influenced by diel periodicity. Recent works have demonstrated diel periodicity of some biochemical variables such as protein activity, cellular $\mathrm{C}$ and $\mathrm{N}$ of the phytoplankton (Vergara et al. 1998, Dolah \& Leighfield 1999, Granum et al. 2002). In addition, changes in metal uptake rate with total ambient metal concentration were examined to ensure that $\mathrm{Cd}$ and $\mathrm{Zn}$ uptake was under saturated at the metal concentration levels used in this study.

\section{MATERIALS AND METHODS}

An axenic culture of Thalassiosira pseudonana (Clone 3H), a common coastal diatom, was obtained from the Provasoli-Guillard Center for the Culture of Marine Phytoplankton, Bigelow Laboratory, Maine, USA. The cells were maintained in $\mathrm{f} / 2$ medium (Guillard \& Ryther 1962) with sterile techniques, in an incubator at $19^{\circ} \mathrm{C}$ with a light illumination of $170 \mu \mathrm{mol}$ photons $\mathrm{m}^{-2} \mathrm{~s}^{-1}$ on a 14:10 h LD cycle. All seawater was collected $10 \mathrm{~km}$ off East Hong Kong to minimize the influence of anthropogenic activities, and was filtered through $0.22 \mu \mathrm{m}$ Poretic membrane before being used in the experiments. The background dissolved $\mathrm{Cd}$ and $\mathrm{Zn}$ concentrations in the seawater were 0.49 and $12.3 \mathrm{nM}$, respectively.

General experimental protocols. We used 2 radiotracers, ${ }^{109} \mathrm{Cd}$ (in $0.1 \mathrm{~N} \mathrm{HCl}$ ) and ${ }^{65} \mathrm{Zn}$ (in $0.1 \mathrm{~N} \mathrm{HCl}$ ), to trace the uptake of stable $\mathrm{Cd}$ and $\mathrm{Zn}$ by the diatoms. They were obtained from New England Nuclear, Boston, USA. The ${ }^{109} \mathrm{Cd}(2.53 \mathrm{nM})$ and ${ }^{65} \mathrm{Zn}(0.02 \mathrm{nM})$ radiotracers, and stable $\mathrm{Cd}$ (nominal concentration of $17.8 \mathrm{nM}$ ) and $\mathrm{Zn}$ (nominal concentration of $76.9 \mathrm{nM}$ ) were spiked into the $0.22 \mu \mathrm{m}$-filtered seawater without any other nutrient addition, and the $\mathrm{pH}$ was adjusted to $8.0 \pm 0.1$ using Suprapure $\mathrm{NaOH}$. This uptake medium was then equilibrated for $12 \mathrm{~h}$ under the same conditions as the uptake period before the uptake experiments. The total concentration of $\mathrm{Cd}$ and $\mathrm{Zn}$ in the uptake medium was 20.8 and $89.2 \mathrm{nM}$, respectively, including the background, radiotracer, and stable metals. The radioactivity of ${ }^{109} \mathrm{Cd}$ (at $88 \mathrm{keV}$ ) and ${ }^{65} \mathrm{Zn}$ (at $1115 \mathrm{keV}$ ) was determined by a Wallac gamma detector. Counting time was adjusted to result in propagated counting errors of $<5 \%$.

The diatoms were acclimated at different temperatures and light conditions before the uptake measurements. A 14:10 h LD cycle was used throughout this study except for the LD cycle experiment. During the acclimation period, the diatoms were grown under different temperatures and light conditions for 4 to $5 \mathrm{~d}$ until they reached mid-exponential growth phase. Cells were enumerated every $12 \mathrm{~h}$ by a Coulter Counter. Cell size was also measured concurrently. The specific growth rate of the cells was quantified as the slope of linear re- 
gression between the natural log of cell density and growth time. When the cells reached mid-exponential phase, they were harvested by filtering gently $(<100 \mathrm{~mm}$ $\mathrm{Hg}$ ) onto the $3 \mu \mathrm{m}$ polycarbonate membrane and then rinsed with $0.22 \mu \mathrm{m}$-filtered seawater 3 times. After a further cell count, they were resuspended in the uptake medium at a cell concentration of $3 \times 10^{5}$ cells $\mathrm{ml}^{-1}$. The light and temperature conditions in the uptake period were the same as those during the acclimation period. Each experimental treatment had 3 replicates. Shortterm uptake took 1 or $4 \mathrm{~h}$. During the uptake period, a $10 \mathrm{ml}$ aliquot was filtered through the $1 \mu \mathrm{m}$ polycarbonate membrane for measurements of the radioactivity in the cells at each time point $(1,2,3$ and $4 \mathrm{~h}$ for the $4 \mathrm{~h}$ uptake, $0.25,0.5,0.75$ and $1 \mathrm{~h}$ for the $1 \mathrm{~h}$ uptake). The metal adsorbed onto the cell wall was removed by Ti-technique wash (Hudson \& Morel 1989, Hutchins et al. 1999). A $2 \mathrm{ml}$ aliquot was also removed for measurement of total radioactivity in the uptake medium. The accumulated content of $\mathrm{Cd}$ and $\mathrm{Zn}$ was calculated as follows:

Accumulated content $\left(\mu \mathrm{g} \mathrm{g}^{-1}\right)=$

(radioactivity $\mathrm{g}^{-1}$ dry cell wt $\times$ total metal

concentration $\left.\mu \mathrm{g} \mathrm{l}^{-1}\right) /\left(\right.$ radioactivity of medium $\mathrm{l}^{-1}$ )

Thus, only the intracellular accumulation of $\mathrm{Cd}$ and Zn was quantified in our study. Cell numbers were counted both at the beginning and end of the uptake experiments. The dry weight of the cells was measured as described by Wang \& Dei (2001).

Uptake kinetics at different ambient $\mathrm{Cd}$ and Zn concentrations. During the acclimation period, the cells were grown at $15^{\circ} \mathrm{C}$ and $340 \mu \mathrm{mol}$ photons $\mathrm{m}^{-2} \mathrm{~s}^{-1}$. When the cells reached mid-exponential phase, they were collected and the metal-uptake experiment was conducted. The experimental $0.22 \mu \mathrm{m}$-filtered seawater used for the uptake medium was first passed through the Chelex 100 resin column and dissolved organic matter was destroyed by UV irradiation (24 h, with removal efficiency close to $100 \%$ ). There were 6 concentration treatments with 2 replicates for each treatment. The total metal concentrations (including the stable metals and radioisotopes) used were 1.28, $3.55,35.5,150,350,1000 \mathrm{nM}$ for $\mathrm{Cd}$, and 1.2, 5.0, 10, 21, 100, $200 \mathrm{nM}$ for $\mathrm{Zn}$. The trace-metal clean technique was used throughout the experiments and all uptake experiments were conducted in a Class 100 clean bench. A Michaelis-Menten equation was used to fit the relationship between the metal uptake rate and the total ambient metal concentration:

$$
V=\frac{V_{\max } C}{K_{\mathrm{m}}+C}
$$

where $V=$ metal uptake rate, $V_{\max }=$ maximum uptake rate when the metal-binding ligands are saturated, $C=$ ambient metal concentration, and $K_{\mathrm{m}}=$ half-saturation constant, defined as the metal concentration when $V$ equals $0.5 V_{\max }$.

Irradiance and temperature experiments. During the acclimation period, the cells were grown at 3 different irradiances $\left(40,170\right.$, and $340 \mu \mathrm{mol}$ photons $\mathrm{m}^{-2}$ $\mathrm{s}^{-1}$ ) and 3 temperatures $\left(15,19\right.$, and $\left.24^{\circ} \mathrm{C}\right)$. Thus, there were a total of 9 different temperature $\times$ irradiance treatments. The cells were grown under these conditions for 4 to $5 \mathrm{~d}$ and the cell concentration was monitored every $12 \mathrm{~h}$. Different irradiances were achieved by using different numbers of white fluorescent tubes and adjusting the distance between the cultures and light sources. When the cells reached mid-exponential phase, metal uptake by the cells was measured over a $4 \mathrm{~h}$ period. In all experiments, uptake was measured simultaneously for each temperature treatment.

Light-dark cycle experiment. The cells were cultured for $6 \mathrm{~d}$ at a light intensity of $170 \mu \mathrm{mol}$ photons $\mathrm{m}^{-2}$ $\mathrm{s}^{-1}$ and at 2 temperatures ( 19 or $24^{\circ} \mathrm{C}$ ). We used 4 different LD cycles: 4:20, 10:14, 16:8 and 24:0 h. No complete dark treatment was included in this experiment because cells did not grow under full-dark conditions over the $6 \mathrm{~d}$ period. In some treatments (i.e. fast cell growth during the acclimation period), the cells were transferred to fresh $\mathrm{f} / 2$ medium to avoid nutrient depletion.

Photosynthetic inhibitors. The concentrations of inhibitors used in our experiments were 5 and $25 \mu \mathrm{M}$ for CCCP and 10, 50 and $150 \mu \mathrm{M}$ for paraquat (Moye et al. 2002). We ran a control treatment without the addition of inhibitors for both the CCCP and the paraquat treatment. The cells were acclimated for 3 to $4 \mathrm{~d}$ at $170 \mu \mathrm{mol}$ photons $\mathrm{m}^{-2} \mathrm{~s}^{-1}$ and $19^{\circ} \mathrm{C}$. Different concentrations of the inhibitors were subsequently added to the cell cultures, and after $2 \mathrm{~h}$ the cells were filtered and resuspended in the uptake medium.

Diel variation. Cells were grown for 3 to $4 \mathrm{~d}$ at $170 \mu \mathrm{mol}$ photons $\mathrm{m}^{-2} \mathrm{~s}^{-1}$ and $19^{\circ} \mathrm{C}$ in a 14:10 LD cycle. The uptake experiments were then conducted over a $24 \mathrm{~h}$ period at 2 to $3 \mathrm{~h}$ intervals in the same LD cycle. During the dark cycle, all the bottles used for the uptake experiments were covered with aluminum foil to minimize any possibility of the cells being exposed to light. All the cells used in the experiments were from the same culture. Each uptake experiment lasted $1 \mathrm{~h}$, and the measurement of metal accumulation was conducted at $15 \mathrm{~min}$ intervals.

\section{RESULTS}

\section{Metal uptake in different metal concentrations, irradiances, and temperatures}

As expected, Cd and $\mathrm{Zn}$ uptake both followed Michaelis-Menten (M-M) uptake kinetics (Fig. 1). $V_{\max }$ 

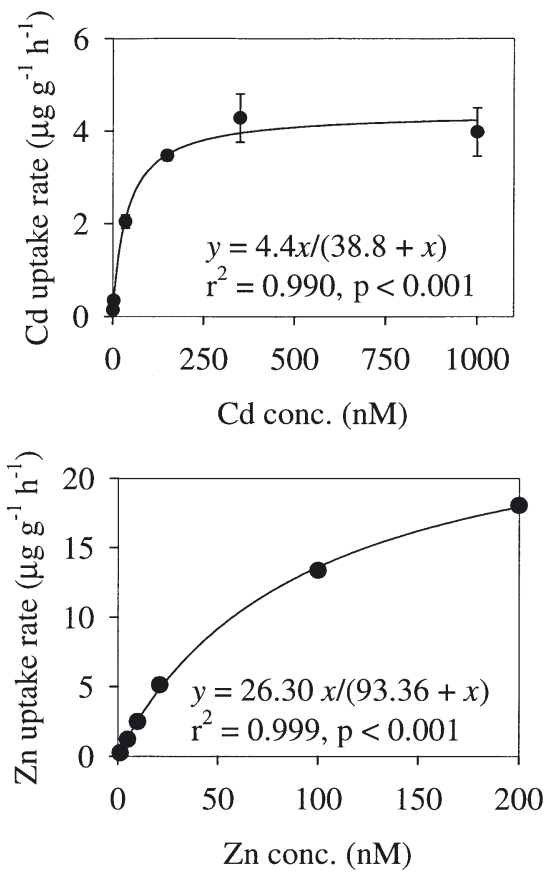

Fig. 1. Thalassiosira pseudonana. Metal uptake rates as a function of total ambient metal concentration. Data are means $\pm \mathrm{SD}(\mathrm{n}=2)$ onto the cell surface (Mirimanoff \& Wilkinson 2000) or the transporter-bound metals after rinsing, and the slope of this regression represented the uptake rate of the metals. Our preliminary experiments also demonstrated that the $y$-intercept represented the initial surface sorption of the cells, since the metal sorption by the heat-killed cells was essentially comparable to the calculated $y$-intercept of the linear regression (data not shown). In general, the accumulated $\mathrm{Cd}$ and $\mathrm{Zn}$ contents at each time point of exposure increased with increasing irradiance levels at each temperature. Additionally, the accumulated contents of $\mathrm{Cd}$ and $\mathrm{Zn}$ were also positively related to temperature. This experiment was repeated, and the trends of metal uptake at different temperatures and irradiances were consistent between the 2 replicated independant experiments.

The calculated intracellular uptake rates of $\mathrm{Cd}$ and $\mathrm{Zn}$ as a function of irradiance levels are shown in Fig. 3. At each temperature, the uptake rates generally increased with increasing irradiance at the 2 lower light levels, but remained rather constant when the irradiance was further increased to $340 \mu \mathrm{mol}$ photons and $K_{\mathrm{m}}$ were $4.4 \mu \mathrm{g} \mathrm{g}^{-1} \mathrm{~h}^{-1}$ and $38.8 \mathrm{nM}$ for $\mathrm{Cd}$, and $26.3 \mu \mathrm{g} \mathrm{g}^{-1} \mathrm{~h}^{-1}$ and $93.4 \mathrm{nM}$ for $\mathrm{Zn}$, respectively. These experiments were conducted using DOC-free seawater. In subsequent experiments, metal uptake was quantified at concentrations below $K_{\mathrm{m}}$ (20.8 nM for Cd and 89.2 nM for $\mathrm{Zn}$ ), but without removal of DOC from the seawater. Since DOC was not removed in subsequent experiments, the resulting free metal concentrations were expected to be much lower than the $K_{\mathrm{m}}$-based free-metal ion concentration.

During the $4 \mathrm{~h}$ uptake period of the temperature and irradiance experiments, the total metal concentrations in the medium decreased by $<15 \%$ for $\mathrm{Zn}$ and $<5 \%$ for Cd. A measurable but small increase of cell number $(<1.2 \times)$ occurred during this period. There was an approximately linear relationship between accumulated metal content and exposure time (between 1 and $4 \mathrm{~h}$ ) (Fig. 2). A previous study indicated that Ti-washing removes 81 and $90 \%$ of extracellular Cd and Zn from diatom cells (Hutchins et al. 1999). The $y$-intercept of the linear regression between accumulated metal content and exposure time represented the amount of metal adsorbed
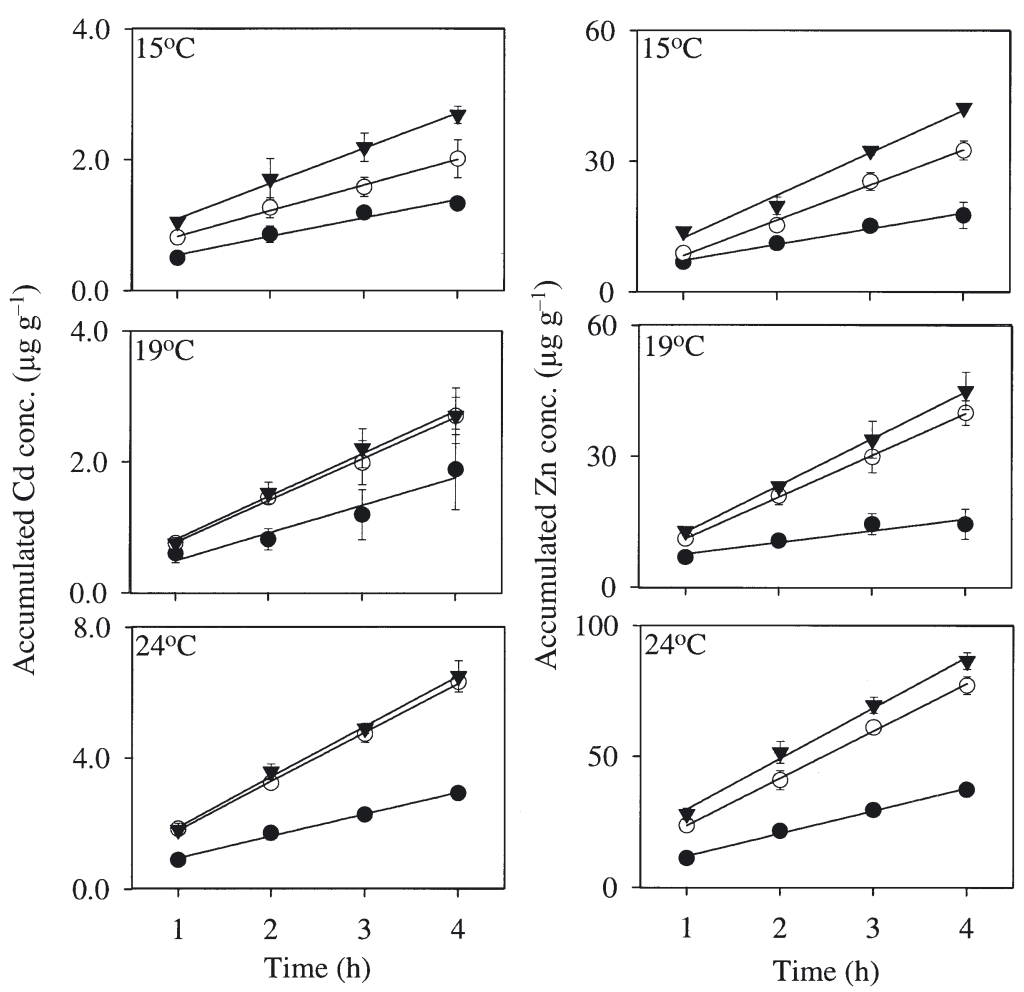

Fig. 2. Thalassiosira pseudonana. Accumulated Cd and Zn content after acclimation to different temperatures and irradiances during short-term uptake period in Expt 2 (only Expt 2 data are presented). Left-hand graphs: Cd uptake; right-hand graphs: Zn uptake. (•) $40 \mu \mathrm{mol}$ photons $\mathrm{m}^{-2} \mathrm{~s}^{-1}$; (○) $170 \mu \mathrm{mol}$ photons $\mathrm{m}^{-2} \mathrm{~s}^{-1}$; ( $\left.\mathbf{(}\right) 340 \mu \mathrm{mol}$ photons $\mathrm{m}^{-2} \mathrm{~s}^{-1}$. Data are means \pm SD $(n=3)$ 
Table 1. Results of 2-way ANOVA of Cd and Zn uptake rates under different irradiances and temperatures. Expts 1 and 2 are 2 different independent experiments

\begin{tabular}{|c|c|c|c|c|c|c|c|c|}
\hline \multirow{2}{*}{ Source } & \multicolumn{4}{|c|}{$\longrightarrow$ Expt 1} & \multicolumn{4}{|c|}{-Expt 2} \\
\hline & $\mathrm{df}$ & MS & $F$ & $\mathrm{p}$ & $\mathrm{df}$ & MS & $F$ & $\mathrm{p}$ \\
\hline \multicolumn{9}{|l|}{ Cd } \\
\hline Temperature $(\mathrm{T})$ & 2 & 0.79 & 284.28 & $<0.001$ & 2 & 1.81 & 179.37 & $<0.001$ \\
\hline Irradiance (I) & 2 & 0.43 & 156.32 & $<0.001$ & 2 & 0.69 & 68.30 & $<0.001$ \\
\hline $\mathrm{T} \times \mathrm{I}$ & 4 & 0.14 & 51.06 & $<0.001$ & 4 & 0.11 & 11.09 & 0.001 \\
\hline Error & 11 & 0.0028 & & & 17 & 0.01 & & \\
\hline \multicolumn{9}{|l|}{ Zn } \\
\hline Temperature $(\mathrm{T})$ & 2 & 252.72 & 368.13 & $<0.001$ & 2 & 173.12 & 172.28 & $<0.001$ \\
\hline Irradiance (I) & 2 & 70.80 & 103.13 & $<0.001$ & 2 & 135.24 & 134.59 & $<0.001$ \\
\hline $\mathrm{T} \times \mathrm{I}$ & 4 & 23.60 & 34.37 & $<0.001$ & 4 & 8.36 & 8,32 & $<0.001$ \\
\hline Error & 17 & 0.69 & & & 17 & 1 & & \\
\hline
\end{tabular}

$\mathrm{m}^{-2} \mathrm{~s}^{-1}$. When irradiance was increased from 40 to $340 \mu \mathrm{mol}$ photons $\mathrm{m}^{-2} \mathrm{~s}^{-1}$, the uptake rates of both metals increased by 2 to $4 \times$, at 15,19 , and $24^{\circ} \mathrm{C}$. A 2-way ANOVA (temperature and irradiance) showed that there was a strong interaction between these 2 factors ( $p<0.001$, Table 1$)$. A 1-way ANOVA (data not shown) indicated that uptake rates of both $\mathrm{Cd}$ and $\mathrm{Zn}$ increased significantly with increasing temperature or irradiance $(p<0.05)$. The most significant influence of irradiance on metal uptake was observed at the 2 lower irradiance levels. The specific growth rates measured in the 2 replicate experiments were highly comparable at different temperatures and irradiances (Fig. 3). Cell size of the diatoms was also concurrently measured for the treatments under different temperatures and irradiances. In general, cell sizes were comparable and not statistically significantly different among the different treatments. The average cell diameter was $5.0 \mu \mathrm{m}$.

We further correlated the relationship between cell-specific growth rate and the cellular uptake rate quantified in the temperature and irradiance experiments (Fig. 4). In general, the uptake rate of $\mathrm{Cd}$ and $\mathrm{Zn}$ increased significantly with increasing growth rate and then leveled off at a high cell-specific growth rate.

\section{Metal uptake in different light-dark cycles}

The accumulated contents of $\mathrm{Cd}$ and $\mathrm{Zn}$ also increased linearly over time in experi-

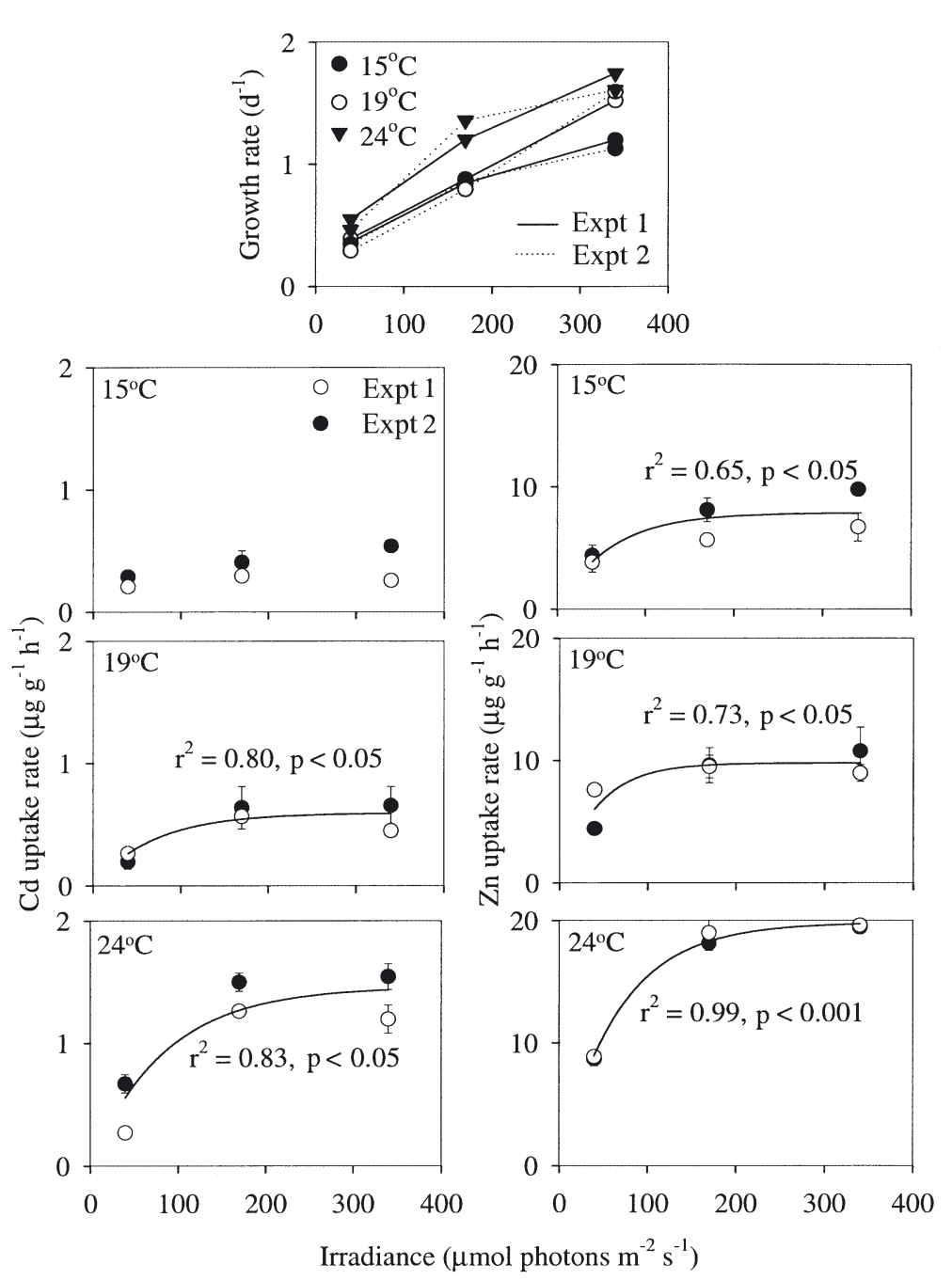

Fig. 3. Thalassiosira pseudonana. Relationships between specific growth rate or $\mathrm{Cd}$ and $\mathrm{Zn}$ uptake rates and the irradiance level. Data are means $\pm \operatorname{SD}(n=3)$ 

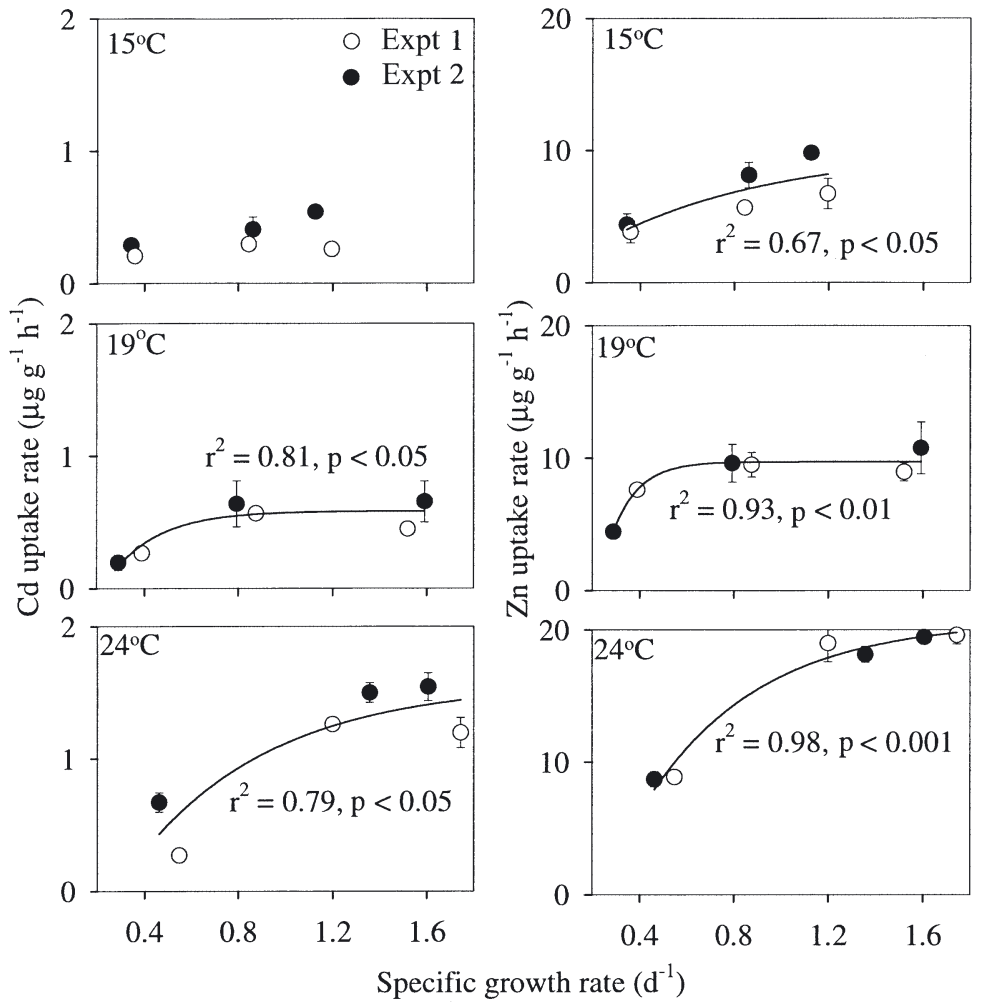

Fig. 4. Thalassiosira pseudonana. Relationship between diatom-specific growth rate and uptake rates $\mathrm{Cd}$ and $\mathrm{Zn}$ at different combinations of temperatures. Specific growth rate was modified by irradiance level. Data are means $\pm \operatorname{SD}(n=3)$

ments with different LD cycles (data not shown). After $4 \mathrm{~h}$ exposure, there was a $2.7 \times$ and $1.8 \times$ increase in the accumulated $\mathrm{Cd}$ content and $1.9 \times$ and $1.4 \times$ increase in intracellular accumulated $\mathrm{Zn}$ content when the cells were maintained under $24 \mathrm{~h}$ light illumination as compared to cells maintained under $4 \mathrm{~h}$ light illumination each day at 19 and $24^{\circ} \mathrm{C}$, respectively. The accumulated intracellular contents of $\mathrm{Cd}$ and $\mathrm{Zn}$ were conspicuously low in the lowest light illumination period $(4 \mathrm{~h})$. The relationship between uptake rate and light exposure period is shown in Fig. 5. At $24^{\circ} \mathrm{C}$, the $\mathrm{Cd}$ and $\mathrm{Zn}$ uptake rates increased by $1.8 \times$ and $1.5 \times$, respectively, when the light illumination period was increased from 4 to 24 $\mathrm{h}$ each day. Similarly, at $19^{\circ} \mathrm{C}, \mathrm{Cd}$ and $\mathrm{Zn}$ uptake rates increased by $2.7 \times$ and $1.7 \times$, respectively. A 1way ANOVA (Table 2) indicated that both temperature and LD cycle significantly affected the uptake of $\mathrm{Cd}$ and $\mathrm{Zn}$ by the diatoms. The specific growth rate of the diatoms also increased with increasing light period (Fig. 5). Similarly, the uptake rates of $\mathrm{Cd}$ and $\mathrm{Zn}$ increased with increasing specific growth rate (Fig. 6).

\section{Metal uptake after addition of inhibitors}

The photosynthetic activity of the diatom cells was inhibited by the 2 inhibitors (CCCP and paraquat at different concentrations), as indicated by the lower cell-specific growth rate in the inhibitor-treated treatments compared to the control treatment during the uptake period $(1.25 \times$ growth in the control treatment vs $1.15 \times$ growth in the $150 \mu \mathrm{M}$ paraquat treatment). The accumulated intracellular metal contents also increased linearly over 1 to $4 \mathrm{~h}$ exposure (data not shown). There was no consistent trend of variations in the accumulated cellular metal content with different concentrations of inhibitors. The calculated uptake rates at different concentrations of inhibitors are shown in Fig. 7. The statistical analysis (Table 2) indicated that there was no significant difference in $\mathrm{Cd}$ uptake for treatments with added CCCP or paraquat. In contrast, the $\mathrm{Zn}$ uptake rate increased with the addition of CCCP and paraquat and then decreased at higher concentrations $(25 \mu \mathrm{M}$ for $\mathrm{CCCP}, 150 \mu \mathrm{M}$ for paraquat).

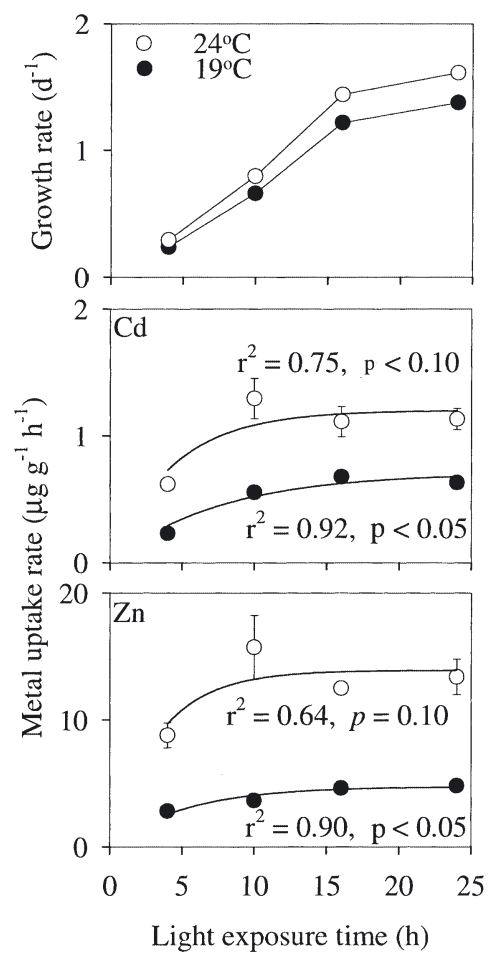

Fig. 5. Thalassiosira pseudonana. Relationship between specific growth rate or $\mathrm{Cd}$ and $\mathrm{Zn}$ uptake rates and light exposure period at 2 different temperatures. Data are means $\pm \mathrm{SD}(\mathrm{n}=3)$ 
Table 2. Results of 1-way ANOVA of Cd and Zn uptake rates in LD cycle, photosynthetic inhibitor and diel-variation experiments. BG: between groups; WG: within groups

\begin{tabular}{|c|c|c|c|c|c|c|c|c|}
\hline \multirow{2}{*}{$\begin{array}{l}\text { Expt } \\
\text { Source }\end{array}$} & \multirow[b]{2}{*}{$\mathrm{df}$} & \multirow[b]{2}{*}{ MS } & \multirow[b]{2}{*}{$F$} & \multirow[b]{2}{*}{$\mathrm{p}$} & \multirow[b]{2}{*}{$\mathrm{df}$} & \multirow[b]{2}{*}{ MS } & \multirow[b]{2}{*}{$F$} & \multirow[b]{2}{*}{$\mathrm{p}$} \\
\hline & & & & & & & & \\
\hline \multicolumn{9}{|l|}{ LD cycle } \\
\hline \multicolumn{9}{|l|}{$19^{\circ} \mathrm{C}$} \\
\hline BG & 3 & 0.117 & \multirow[t]{2}{*}{53.382} & \multirow[t]{2}{*}{$<0.001$} & 3 & 3.358 & \multirow[t]{2}{*}{9.344} & \multirow[t]{2}{*}{0.005} \\
\hline WG & 8 & 0.002 & & & 8 & 0.359 & & \\
\hline \multicolumn{9}{|l|}{$24^{\circ} \mathrm{C}$} \\
\hline BG & 3 & 0.252 & \multirow[t]{2}{*}{21.801} & \multirow[t]{2}{*}{$<0.001$} & 3 & 32.158 & \multirow[t]{2}{*}{13.42} & \multirow[t]{2}{*}{0.002} \\
\hline WG & 8 & 0.012 & & & 8 & 2.396 & & \\
\hline \multicolumn{9}{|l|}{ Inhibitor } \\
\hline \multicolumn{9}{|l|}{ СССР } \\
\hline BG & 2 & 0.010 & \multirow{2}{*}{3.57} & \multirow[t]{2}{*}{0.07} & 2 & 10.33 & \multirow[t]{2}{*}{11.51} & \multirow[t]{2}{*}{0.003} \\
\hline WG & 9 & 0.003 & & & 9 & 0.90 & & \\
\hline \multicolumn{9}{|c|}{ Paraquat } \\
\hline BG & 3 & 0.009 & \multirow[t]{2}{*}{3.01} & \multirow[t]{2}{*}{0.09} & 3 & 9.12 & \multirow[t]{2}{*}{8.08} & \multirow[t]{2}{*}{0.008} \\
\hline WG & 8 & 0.029 & & & 8 & 1.13 & & \\
\hline \multicolumn{9}{|c|}{ Diel variation } \\
\hline BG & 7 & 0.087 & \multirow[t]{2}{*}{12.88} & \multirow[t]{2}{*}{$<0.001$} & 7 & 0.79 & \multirow[t]{2}{*}{1.27} & 0.3301 \\
\hline WG & 13 & 0.007 & & & 15 & 0.62 & & \\
\hline
\end{tabular}

\section{Diel variations in metal uptake}

The diatom cells were maintained in a 14:10 h LD cycle and metal accumulation was quantified at different periods of the day. The accumulated intracellular contents of $\mathrm{Cd}$ and Zn increased linearly with exposure time for diatoms harvested at different diel periods (data not shown). The calculated $\mathrm{Cd}$ and $\mathrm{Zn}$ uptake rates at different diel periods (over $24 \mathrm{~h}$ ) are shown in Fig. 8. In general, Cd uptake rates were in the range of 0.53 to $1.20 \mu \mathrm{g} \mathrm{g}^{-1} \mathrm{~h}^{-1}$, with most ranging from 0.60 to $0.90 \mu \mathrm{g} \mathrm{g}^{-1} \mathrm{~h}^{-1}$; and $\mathrm{Zn}$ uptake rates were in the range 3.90 to $4.90 \mu^{-1} \mathrm{~g} \mathrm{~g}^{-1}$, with 1 exception (5.35 $\mu \mathrm{g}$ $\mathrm{g}^{-1} \mathrm{~h}^{-1}$ measured at 08:00 $\left.\mathrm{h}\right)$. There was no consistent trend in $\mathrm{Cd}$ uptake rate as a function of diel period, although the statistical analysis indicated that diel period did significantly affect the uptake of $\mathrm{Cd}(\mathrm{p}<$ 0.05, 1-way ANOVA) (Table 2). Conversely, there was no diel variation in $\mathrm{Zn}$ uptake between diel periods $(p>0.05,1$ way ANOVA).

\section{DISCUSSION}

Both $\mathrm{Cd}$ and $\mathrm{Zn}$ uptake rates quantified in this study were comparable to those in previous studies on the same diatom species under similar conditions (Wang et al. 2001). In addition, the calculated $V_{\max }$ was
1

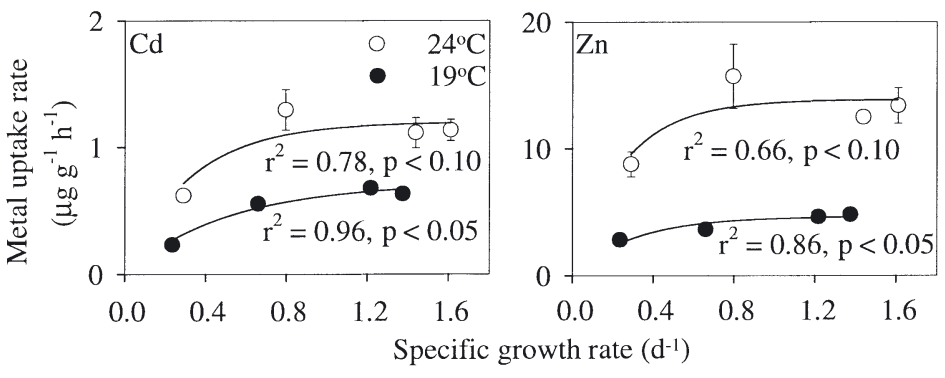

Fig. 6. Thalassiosira pseudonana. Relationship between specific growth rate and $\mathrm{Cd}$ and $\mathrm{Zn}$ uptake rates at 2 temperatures. Specific growth rate was modified by light exposure period. Data are means \pm $\mathrm{SD}(\mathrm{n}=3)$
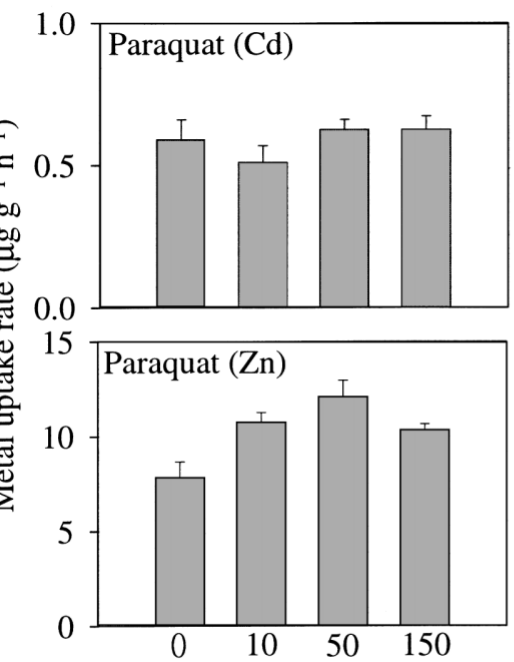
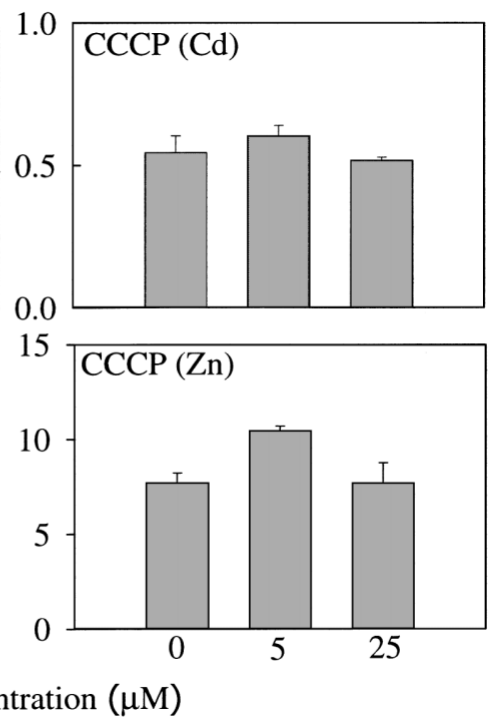

Fig. 7. Thalassiosira pseudonana. Cd and $\mathrm{Zn}$ uptake rates after addition of different concentrations of inhibitors. Data are means \pm SD $(n=3)$ 


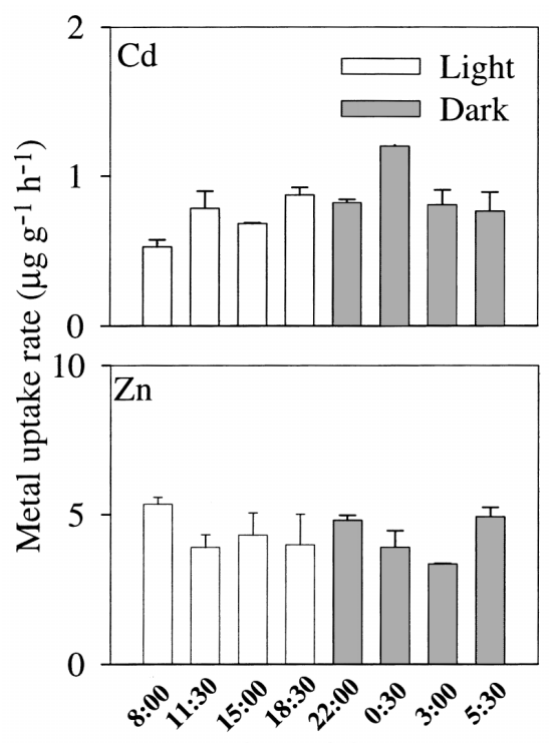

Time of day

Fig. 8. Thalassiosira pseudonana. Diel variations in $\mathrm{Cd}$ and $\mathrm{Zn}$ uptake rates during a $24 \mathrm{~h}$ diel period. Data are means $\pm \mathrm{SD}$ $(\mathrm{n}=3)$

also comparable to those measured in previous studies (Sunda \& Huntsman 1998c). Since it was difficult to accurately calculate the free-ion $\mathrm{Cd}$ and $\mathrm{Zn}$ concentrations with MINEQL+ (a chemical equilibrium modeling system, Version 4.5 for Windows) without using the buffer solution for the uptake medium, direct comparison of the $K_{\mathrm{m}}$ with previous studies was not possible. In our short-term uptake experiments $(4 \mathrm{~h})$, there was a possibility of interference by metal efflux from the cells; thus, the quantified metal uptake may only represent the net uptake rate. However, within such a short exposure period $(<4 \mathrm{~h})$, the metal efflux may be considered negligible compared to the much higher metal influx rate (e.g. as found for Thalassiosira weissflogii: Lee et al. 1996; Chlorella kesslerii: Hassler \& Wilkinson 2003).

In this study, we have demonstrated that temperature and irradiance significantly influence the uptake rates of $\mathrm{Cd}$ and $\mathrm{Zn}$ by the diatom Thalassiosira pseudonana. Increased temperature and irradiance both enhance $\mathrm{Cd}$ and $\mathrm{Zn}$ uptake by the cells. Furthermore, temperature and irradiance interact in their influences on metal uptake. With irradiance and temperature constant, changes in the LD cycle also impact the uptake of metals by the cells. Light and temperature both control the photosynthesis of the cells. Previous studies have shown that the biochemical composition and cell size of phytoplankton differ for cells acclimated under different light and temperature conditions (Berges \& Harrison 1993, Lin \& Carpenter 1997,
Berges et al. 2002, Hammer et al. 2002, Staehr et al. 2002). For example, cellular N, chlorophyll $a$ and the $\mathrm{C}: \mathrm{N}$ ratio increase with increasing temperature (Berges et al. 2002). Furthermore, there is also a diel variation in cellular composition and cell size (Durand \& Olson 1998, Vergara et al. 1998, Granum et al. 2002) as well as a diel pattern in the cell cycle (Dolah \& Leighfield 1999). For example, in a study on the marine diatom Skeletonema costatum, the cellular organic N increased from $2.4 \mathrm{pg}^{\mathrm{cell}}{ }^{-1}$ at the beginning of the photophase to $3.3 \mathrm{pg}^{\mathrm{pell}}{ }^{-1}$ at the end of the photophase, and then decreased again to $2.5 \mathrm{pg} \mathrm{cell}^{-1}$ (end of the scotophase) (Granum et al. 2002). All these biochemical, biovolume and cell-cycle changes may potentially lead to a change in metal uptake rate as influenced by temperature, irradiance, and LD cycle.

To determine whether the uptake of $\mathrm{Cd}$ and $\mathrm{Zn}$ is dependent on the phytoplankton's photosynthetic activity, which can be affected by temperature and light, we used 2 inhibitors (carbonyl cyanide mchlorophenylhydrazone $\mathrm{CCCP}$, and the herbicide paraquat) to block the photosynthesis of the cells (Moye et al. 2002, Hassler \& Wilkinson 2003). CCCP can disconnect electron transport from ATP synthesis, thereby inhibiting photophosphorylation and preventing the formation of ATP required for energy supply. Paraquat acts at the reducing end of Photosystem I by inhibiting ferredoxin reduction and ATP production. In our experiments, the uptake rate of $\mathrm{Zn}$ increased rather unexpectedly with the addition of 2 inhibitors at different concentrations compared to the control treatment. The reason for this is not known, although Moye et al. (2002) also found that paraquat enhanced the accumulation of methylmercury by the green alga Selenastrum capricornutum. However, Moye et al. (2002) showed that additions of CCCP at the same concentrations as those used in our study ( 5 and $25 \mu \mathrm{M}$ ) abruptly decreased methylmercury uptake by $85 \%$. Hassler \& Wilkinson (2003) also demonstrated that the addition of the inhibitors $\mathrm{CCCP}$ and vanadate (BDH) significantly reduced (by up to $95 \%$ ) the uptake of $\mathrm{Zn}$ by Chlorella kesslerii. The results of our study suggest that the uptake of $\mathrm{Cd}$ and $\mathrm{Zn}$ by the diatoms was not affected by photosynthetic activity, which was closely related to the temperature and light conditions.

Previous studies have demonstrated that cell size (Durand \& Olson 1998), cell cycle (Dolah \& Leighfield 1999), enzyme activity (e.g. nitrate reductase) (Vergara et al. 1998), and cellular $\mathrm{N}$ and $\mathrm{C}$ (Granum et al. 2002) exhibit considerable diel patterns. In our experiments, generally there was no consistent or notable pattern of diel variations in $\mathrm{Cd}$ and $\mathrm{Zn}$ uptake by the diatoms. Furthermore, there was no significant difference among most of the uptake rates quantified over $24 \mathrm{~h}$ for $\mathrm{Cd}$ (although the differences were significant when all 
treatments were tested together; Table 2). However, metal accumulation increased significantly with increasing light illumination period, e.g. a $2.7 \times$ and $1.7 \times$ increase in $\mathrm{Cd}$ and $\mathrm{Zn}$ uptake rate, respectively, at $19^{\circ} \mathrm{C}$ with an increase in the light period from 4 to $24 \mathrm{~h}$ each day. Consequently, the diel cycle in the morphology, physiology or biochemistry of the diatoms was not responsible for the correlation between the uptake rate and the LD cycle, despite the fact that cells under different LD cycles may show different cell cycles.

Cell size of diatoms has been reported to increase with increasing irradiance (Thalassiosira pseudonana: Harrison et al. 1990) and temperature (T. weissflogii: Lomas \& Glibert 1999) or to remain constant (T. pseudonana: Berges et al. 2002; Skeletonema costatum: Gao et al. 2000). Cell size also tended to increase when diatom Thalassiosira pseudonana was cultured under a LD cycle compared with continuous light (Berges et al. 2002). In our study, we did not find any significant change in the cell size of T. pseudonana (which could substantially affect the metal uptake due to a change in the surface area-to-volume ratio). Cell size can thus be ruled out as controlling metal uptake at different temperatures and light conditions. Additionally, the $\mathrm{N}$ content of diatoms (as an index of the protein content) was almost constant regardless of changes in temperature and light (Harrison et al. 1990, Berges et al. 2002). Thus, biochemical composition, cell size and changes in metabolism or photosynthetic activity were not responsible for the relationship between metal uptake and irradiance or the LD cycle observed in this study. Furthermore, the metal-binding sites were not saturated according to our kinetic uptake experiments; thus, the leveling-off of the metal-uptake rate under higher irradiances was unlikely to have been due to the saturation of surface metal-binding sites.

In our study, we found that the uptake rates of both $\mathrm{Cd}$ and $\mathrm{Zn}$ increased significantly with increasing cellspecific growth rate in both replicate experiments with different combinations of temperature and irradiance. It appears that there was a hyperbolic relationship between the uptake rate and the specific growth rate. At the lowest temperature $\left(15^{\circ} \mathrm{C}\right)$, the maximum cellspecific growth rate was only $1.2 \mathrm{~d}^{-1}$, and the hyperbolic relationship between the uptake rate and the specific growth rate became less apparent. At this temperature, the Zn uptake rate increased linearly with increasing specific growth rate in each replicated experiment. A similar hyperbolic correlation was also evident in the LD cycle experiment. In an early study, Wang \& Dei (2001) described a positive linear or exponential correlation between specific growth rate and the uptake rate of $\mathrm{Cd}$, Se and $\mathrm{Zn}$ in different species of marine phytoplankton. In their study, the specific growth rate of the cells was affected by different addi- tions of macronutrients, while we used light and temperature to modify the cell-specific growth rate in this study. Because both the cell-specific growth rate and the uptake rate of metals can depend on macronutrients, a correlation such as that found by Wang \& Dei (2001) cannot be considered a definite proof of the direct dependence of metal uptake rate on cell growth rate. For example, algal cells maintained under $\mathrm{N}$ enriched conditions may be able to synthesize more ligands for metal transport (and display a high uptake rate), while also increasing growth. In this study, we have shown that cellular metabolism and photosynthetic activity induced by changes in temperature, irradiance and the LD cycle has little effect on metal uptake. Consequently, the metal uptake rate may be potentially dependent on the specific growth rate of the diatoms.

Under steady-state conditions, the cellular metal content of phytoplankton can be calculated as the metal uptake rate divided by the cell-specific growth rate (Sunda 1989, Sunda \& Huntsman 1998a). Sunda \& Huntsman (1998a) summarized the feedback relationships between cellular metal content and specific growth rate, as well as between cellular metal content and uptake rate in marine phytoplankton. However, it remains unclear whether there is any interrelationship between uptake rate and specific growth rate. Our study has indicated that when cell growth increases under certain conditions, then uptake rate will initially increase in proportion with the cell-specific growth rate, thus maintaining the same cellular metal content. $\mathrm{Zn}$ is a cofactor of some enzymes such as carbonic anhydrase, DNA and RNA polymerases, and alkaline phosphase (Price \& Morel 1990, Lee et al. 1995). Thus, the physiological requirement for $\mathrm{Zn}$ may increase with the growth of the phytoplankton, leading to a higher $\mathrm{Zn}$ uptake rate. This can be considered as positive feedback between uptake rate and specific growth rate. When cell-specific growth rate reaches a higher level, then uptake rate is unable to keep pace, and cellular content will decrease accordingly. In this connection, growth rate can equally well be described as negative feedback regulation.

The relationship between specific growth rate and uptake rate has a significant implication in the metal dynamics during phytoplankton blooms (e.g. eutrophication or spring blooms). Luoma et al. (1998) found that particulate $\mathrm{Cd}$ and $\mathrm{Zn}$ concentrations ( $\mathrm{nmol} \mathrm{l^{-1 }}$ ) in San Francisco Bay increased by $6 \times$ and $3 \times$, respectively, during the spring bloom period. Our study implies that such an abrupt increase in particulate $\mathrm{Cd}$ and $\mathrm{Zn}$ concentrations in natural phytoplankton may be due to the proportionally higher $\mathrm{Cd}$ and $\mathrm{Zn}$ uptake rates paralleling the higher specific growth rate during the bloom period. Such an almost proportional increase in both 
metal uptake rates as well as cell-specific growth rate also explains why there was a much smaller increase for $\mathrm{Cd}$ and $\mathrm{Zn}$ content $\left(\mathrm{nmol} \mathrm{g}{ }^{-1}\right.$ ) in the phytoplankton ( $2 \times$ and $1.1 \times$ in $\mathrm{Cd}$ and $\mathrm{Zn}$, respectively). However, the interrelationship between these 2 parameters still needs to be tested further under field conditions. In addition, there was a significant difference between $\mathrm{Cd}$ and $\mathrm{Zn}$ uptake at different temperatures, but with similar growth rates. Temperature may significantly affect the uptake rates of $\mathrm{Cd}$ and $\mathrm{Zn}$ by other metabolic processes in addition to those controlled by cell growth rate. The mechanisms contributing to such marked difference remain unknown.

Our study has demonstrated that the metal uptake rate of the diatoms is dependent on their growth rates, which should be taken into consideration when examining the interrelationship between the cellular metal concentration, uptake rate and growth rate. Such an interrelationship can be potentially responsible for the observed increase in particulate metal concentration during phytoplankton blooms and the survival of phytoplankton under conditions of sublethal metal concentrations. It should be noted that the interaction between metal uptake rate and growth rate was not indirectly exerted through changes in cellular metal content. However, the cellular mechanisms underlying the interrelationship between the uptake rate and growth rate need to be further studied. Whether or not this relationship exists with other metals and in other phytoplankton species also needs to be examined.

Acknowledgements. We thank the anonymous reviewers for their very constructive and helpful comments on this work. This study was supported by a Competitive Earmarked Research Grant from the Hong Kong Research Grants Council (HKUST6118/01M, and N_HKUST603/01) to W.-X.W.

\section{LITERATURE CITED}

Berges JA, Harrison PJ (1993) Relationship between nucleoside diphosphate kinase activity and light-limited growth rate in the marine diatom Thalassiosira pseudonana (Bacillariophyceae). J Phycol 29:45-53

Berges JA, Varela DE, Harrison PJ (2002) Effects of temperature on growth rate, cell composition and nitrogen metabolism in the marine diatom Thalassiosira pseudonana (Bacillariophyceae). Mar Ecol Prog Ser 225:139-146

Bruland KW, Donat JR, Hutchins DA (1991) Interactive influences of bioactive trace metal on biological production in oceanic waters. Limnol Oceanogr 36:1555-1577

Campbell PGC (1995) Interactions between trace metals and aquatic organisms: a critique of the free-ion activity model. Metal speciation and bioavailability in aquatic systems. John Wiley \& Sons, Chichester, p 45-102

Cullen JT, Lane TW, Morel FMM, Sherrell RM (1999) Modulation of cadmium uptake in phytoplankton by seawater $\mathrm{CO}_{2}$ concentration. Nature 402:165-167
Cullen JT, Chase Z, Coale KH, Fitzwater SE, Sherrell RM (2003) Effect of iron limitation on the cadmium to phosphorus ratio of natural phytoplankton assemblages from the Southern Ocean. Limnol Oceanogr 48:1079-1087

Dolah FMV, Leighfield TA (1999) Diel phasing of the cellcycle in the Florida red tide dinoflagellate, Gymnodinium breve. J Phycol 35:1404-1411

Durand MD, Olson RJ (1998) Diel patterns in optical properties of the chlorophyte Nannochloris sp.: relating individual-cell to bulk measurements. Limnol Oceanogr 43:1107-1118

Gao Y, Smith G, Alberte R (2000) Temperature dependence of nitrate reductase activity in marine phytoplankton: biochemical analysis and ecological implications. J Phycol 36: 304-313

Granum E, Kirkvold S, Myklestad SM (2002) Cellular and extracelluar production of carbohydrates and amino acids by the marine diatom Skeletonema costatum: diel variations and effects of N depletion. Mar Ecol Prog Ser 242: 83-94

Guillard RRL, Ryther JH (1962) Studies on marine planktonic diatoms. I. Cyclotella nana hustedt and Detonula confervacea (Cleve) Gran. Can J Microbiol 8:229-239

Hammer A, Schumann R, Schubert H (2002) Light and temperature acclimation of Rhodomanas salina (Cryptophyceae): photosynthetic performance. Aquat Microb Ecol 29:287-296

Harrison PJ, Thompson PA, Calderwood GS (1990) Effects of nutrient and light limitation on the biochemical composition of phytoplankton. J Appl Phycol 2:45-56

Hassler CS, Wilkinson KJ (2003) Failure of the biotic ligand and free-ion activity models to explain zinc bioaccumulation by Chlorella kesslerii. Environ Toxicol Chem 22:620-626

Hudson RJM, Morel FMM (1989) Distinguishing between extra- and intracellular iron in marine phytoplankton. Limnol Oceanogr 34:1113-1120

Hudson RJM, Morel FMM (1990) Iron transport in marine phytoplankton: kinetics of cellular and medium coordination reactions. Limnol Oceanogr 35:1002-1020

Hutchins DA, Wang WX, Schmidt MA, Fisher NS (1999) Dual labeling techniques for trace metal biogeochemical investigations in aquatic plankton communities. Aquat Microb Ecol 19:129-138

Lee JF, Roberts SB, Morel FMM (1995) Cadmium: a nutrient for the marine diatom Thalassiosira weissflogii. Limnol Oceanogr 40:1056-1063

Lee JF, Ahner BA, Morel FMM (1996) Export of cadmium and phytochelatin by the marine diatom Thalassiosira weissflogii. Environ Sci Technol 30:1814-1821

Lin S, Carpenter EJ (1997) Rubisco of Dunaliella tertiolecta is redistributed between the pyrenoid and the stroma as a light/shade response. Mar Biol 127:521-529

Lomas MW, Glibert PM (1999) Interactions between $\mathrm{NH}_{4}{ }^{+}$ and $\mathrm{NO}_{3}{ }^{-}$uptake and assimilation: comparisons of diatoms and dinoflagellates at several growth temperatures. Mar Biol 133:541-545

Luoma SN, Geen AV, Lee BG, Cloern JE (1998) Metal uptake by phytoplankton during a bloom in South San Francisco Bay: implications for metal cycling in estuaries. Limnol Oceanogr 43:1007-1016

Mirimanoff N, Wilkinson KJ (2000) Regulation of Zn accumulation by a freshwater gram-positive bacterium (Rhodococcus opacus). Environ Sci Technol 34:616-622

Moye A H, Miles CJ, Philips EJ, Sargent B, Merritt KK (2002) Kinetics and uptake mechanisms for monomethymercury between freshwater algae and water. Environ Sci Technol 36:3550-3555 
Price NM, Morel FMM (1990) Cadmium and cobalt substitution for zinc in a marine diatom. Nature 344:658-660

Staehr PA, Henriksen P, Markager P (2002) Photoacclimation of four marine phytoplankton species to irradiance and nutrient availability. Mar Ecol Prog Ser 238:47-59

Sunda WG (1989) Trace metal interactions with marine phytoplankton. Biol Oceanogr 6:411-442

Sunda WG, Huntsman SA (1998a) Processes regulating cellular metal accumulation and physiological effects: phytoplankton as model systems. Sci Total Environ 219:165-181

Sunda WG, Huntsman SA (1998b) Interactive effects of external manganese, the toxic metals copper and zinc, and light in controlling cellular manganese and growth in a coastal diatom. Limnol Oceanogr 43:1467-1475

Sunda WG, Huntsman SA (1998c) Control of Cd concentrations in a coastal diatom by interactions among free ionic $\mathrm{Cd}, \mathrm{Zn}$,

Editorial responsibility: Otto Kinne (Editor),

Oldendorf/Luhe, Germany and Mn in seawater. Environ Sci Technol 32:2961-2968

Sunda WG, Huntsman SA (2000) Effect of Zn, Mn, and Fe on $\mathrm{Cd}$ accumulation in phytoplankton: implications for oceanic Cd cycling. Limnol Oceanogr 45:1501-1516

Vergara JJ, Berges JA, Falkowski PG (1998) Diel periodicity of nitrate reductase activity and protein levels in the marine diatom Thalassiosira pseudonana (Bacillariophyceae). J Phycol 34:952-961

Wang WX, Dei RCH (2001) Effects of major nutrient additions on metal uptake in phytoplankton. Environ Pollut 111: $233-240$

Wang WX, Dei RCH, Xu Y (2001) The responses of Zn assimilation by coastal plankton to macronutrients. Limnol Oceanogr 46:1524-1534

Whitfield M (2001) Interactions between phytoplankton and trace metals in the ocean. Adv Mar Biol 41:1-128

Submitted: July 18, 2003; Accepted: March 16, 2004

Proofs received from author(s): June 16, 2004 